\title{
The ARDSnet protocol may be detrimental in COVID-19
}

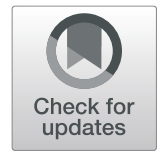

\author{
Vasiliki Tsolaki ${ }^{*}$, George E. Zakynthinos and Dimosthenis Makris
}

To the Editor,

Intensive care units are overwhelmed with COVID-19 ARDS patients during the last months, and increased mortality has been reported [1]. The Surviving Sepsis Campaign-COVID-19 guidelines and, recently, the American Thoracic Society (ATS) proposed to treat COVID-19 per ARDSnet protocol [2, 3]. However, there are a few issues we would like to address concerning the ventilatory strategy and fluid administration. Heart-lung interactions may play a crucial role, especially in the management of COVID-19 patients.

In the largest series of almost 1600 COVID-19 ICU patients, the median $\mathrm{PaO}_{2} / \mathrm{FiO}_{2}$ was 160 and the median PEEP used was $14 \mathrm{cmH}_{2} \mathrm{O}$ [1]. It seems that PEEP was set according to predefined criteria (ARDSnet, SSCCOVID-19 guidelines, ATS statement) [2, 3]. However, COVID-19 ARDS does not seem to be "typical" [4]. In patients from our unit, the median static compliance was $52 \mathrm{ml} / \mathrm{cmH}_{2} \mathrm{O}$, and this seems to be the case in most intubated patients in Greece (compliance of $50-65 \mathrm{ml} /$ $\mathrm{cmH}_{2} \mathrm{O}$, anecdotal reports) and other countries [4]. In our patients, the mean $\mathrm{PaO}_{2} / \mathrm{FiO}_{2}$ value was 89. If we had followed the suggested protocols, we should have applied a PEEP of $18 \mathrm{cmH}_{2} \mathrm{O}$. Contrary, a median PEEP of $8 \mathrm{cmH}_{2} \mathrm{O}$ was the "best" PEEP, evaluated combining respiratory variables (compliance, FRC, $\mathrm{PaCO}_{2}$ ) and hemodynamics through echocardiography (RV function, SPAP through tricuspid regurgitation). Trials of increased PEEP worsened hemodynamics and increased vasopressors. In most cases, fluid administration was decided considering inferior vena cava distensibility index and pulse pressure variation (tidal volume set at $8 \mathrm{ml} / \mathrm{kg}$ ).

\footnotetext{
* Correspondence: vasotsolaki@yahoo.com

Intensive Care Unit, University Hospital of Larissa, University of Thessaly, Faculty of Medicine, Larissa, Greece
}

(c) The Author(s). 2020 Open Access This article is licensed under a Creative Commons Attribution 4.0 International License, which permits use, sharing, adaptation, distribution and reproduction in any medium or format, as long as you give appropriate credit to the original author(s) and the source, provide a link to the Creative Commons licence, and indicate if changes were made. The images or other third party material in this article are included in the article's Creative Commons licence, unless indicated otherwise in a credit line to the material. If material is not included in the article's Creative Commons licence and your intended use is not permitted by statutory regulation or exceeds the permitted use, you will need to obtain permission directly from the copyright holder. To view a copy of this licence, visit http://creativecommons.org/licenses/by/4.0/ The Creative Commons Public Domain Dedication waiver (http://creativecommons.org/publicdomain/zero/1.0/) applies to the data made available in this article, unless otherwise stated in a credit line to the data.

It is well-known that when lung compliance is relatively normal, even more than $50 \%$ of the alveolar pressure is transmitted to the pleural pressure. Relatively high PEEP (in a non-recruitable lung) may have a detrimental impact on hemodynamics, deteriorating venous return. Moreover, application of high PEEP when notneeded unnecessarily increases transpulmonary pressure forcing West's zone 3 lung regions to zones 2 and 1 , leading to dead space ventilation and increasing pulmonary vascular resistance [5]. Both effects are exacerbated in hypovolemic patients. Therefore, fluid restriction may not be so applicable in SARS-COV-2 ARDS. Hypovolemia and hemodynamic compromise in hypertensive patients might contribute to the observed increased mortality in those patients receiving diuretics as standard treatment, as hemodynamic instability leads to organ hypoperfusion and ultimately fatal multiorgan failure [1].

It seems that in most SARS-CoV-2 patients, we have to abandon the ARDSnet protocol (high-PEEP, low-Vt). Point-of-care echocardiography may guide decisions.

\section{Acknowledgements \\ None}

Authors' contributions observations on the management of COVID-19 mechanically ventilated ARDS patients. The author(s) read and approved the final manuscript.

Funding

None

Availability of data and materials Not applicable

Ethics approval and consent to participate Not applicable

Consent for publication

Not applicable

Competing interests

Not applicable 
Received: 23 April 2020 Accepted: 9 June 2020

Published online: 16 June 2020

\section{References}

1. Grasseli G, Zangrillo A, Zanella A, Antonelli M, Cabrini L, Castelli A, et al. Baseline charecteristics and outcomes of 1591 patients infected with SARSCoV-2 admitted to ICUs of the Lombardy Region, Italy. JAMA 2020 doi: https://doi.org/10.1001/jama.2020.4031.

2. Alhazzani W, Møller M, Arabi Y, Loeb M, Gong MN, Fan E, et al. Surviving Sepsis Campaign: guidelines on the management of critically ill. Intensive Care Med Mar. 2020;28:1-34. https://doi.org/10.1007/s00134-020-06022-5.

3. Jamil S, Mark N, Carlos G, Dela Cruz C, Gross J, Pasnick S. Diagnosis and management of COVID-19 disease. AJRCCM. 2020. https://doi.org/10.1164/ rccm.2020C1.

4. Gattinoni L, Coppola S, Cressoni M, Busana M, Rossi S, Chiumello D. COVID19 does not lead to a "typical" acute respiratory distress syndrome. Am J Resp Crit Care Med. 2020. https://doi.org/10.1164/rccm.202003-0817LE.

5. Gattinoni L, Chiumello D, Rossi S. COVID-19 pneumonia: ARDS or not? Crit Care. 2020;24:154. https://doi.org/10.1186/s13054-020-02880-z.

\section{Publisher's Note}

Springer Nature remains neutral with regard to jurisdictional claims in published maps and institutional affiliations. 